\title{
Metabolic activity of size-fractionated microbial plankton in estuarine, nearshore, and continental shelf waters of Georgia
}

\author{
P. C. Griffith*, D. J. Douglas**, S. C. Wainright*** \\ Institute of Ecology, University of Georgia, Athens 30602, USA
}

\begin{abstract}
Estimates of bacterial production and activity, and of planktonic community respiration, were made at a series of stations starting in an estuary, passing through the coastal front, and across the continental shelf to a distance of $120 \mathrm{~km}$ offshore in the Georgia Bight. Measurements were made on unfiltered and on $1.0 \mu \mathrm{m}$ (pore-size) filtered water samples to examine the small free-living bacterial size fraction relative to the larger plankton. In waters landward of the coastal front, ca 50 to $80 \%$ of bacterial and community activity was associated with the larger size fraction, indicating the importance of larger and particle-associated heterotrophs in the nearshore, highly turbid water. Seaward of the front, 80 to $99 \%$ of activity was in the $<1.0 \mu \mathrm{m}$ fraction. Thus, the $<1.0 \mu \mathrm{m}$ size fraction is responsible for most of the respiration in shelf-waters. Bacterial production and activity decreased markedly with distance from shore; community respiration also decreased across the shelf, but not as much as the bacterial production decreased. Bacterial growth efficiency was low in estuarine waters (11\%), and decreased in nearshore $(6 \%)$ and shelf $(2 \%)$ waters.
\end{abstract}

\section{INTRODUCTION}

Within the last $20 \mathrm{yr}$ it has been established that bacteria are responsible for much of the heterotrophic activity in the sea (Pomeroy \& Johannes 1966, 1968, Williams 1981, 1984, Pomeroy 1974). Much attention has focused on the relative number of these microorganisms that are associated with particulate matter versus those that are free-living (Wiebe \& Pomeroy 1972, Hanson \& Wiebe 1977. Hodson et al. 1981, Ducklow \& Kirchman 1983, Smith et al. 1986, roviowed by Wangersky 1984). Results vary, but it appears, based on comparisons of data from different investigators working in different waters, that attached bacteria are important in waters where particles are abundant (Wangersky 1984). In this study we examined the role of free-living bacteria relative to the rest of the planktonic community in coastal waters of the southeastern

Present addresses:

- Center of Marine Biotechnology, 600 E. Lombard St., Baltimore, Maryland 21202, USA

- Atlantic Research Laboratory, National Research Council, Halifax, Nova Scotia, Canada B3H 3 Z1

.. Ecosystem Center, Marine Biological Laboratory, Woods Hole, Massachusetts 02543, USA
USA, where the amount of suspended particulate matter varies greatly but predictably.

Characteristic of the shallow ocean-waters of the southeastern USA is a frontal zone, 10 to $20 \mathrm{~km}$ wide, of highly turbid water. Called nearshore water, the zone is formed by a pressure gradient induced by the freshwater discharge of rivers and estuaries, and balanced by geostrophic forces (Blanton 1981). The coastal front presents a barrier to the seaward transport of dissolved and particulate material from estuarine and nearshore waters to shelf waters, which are typically less turbid than nearshore waters (Blanton 1981).

The markedly higher particulate content of estuarine and nearshore waters leads to the expectation that particle-associated bacteria would be more important there than in shelf water. The presence of a boundary between nearshore and shelf waters presented the opportunity to study the roles of free-living and particle-associated bacteria in adjacent, but markedly dissimilar, conditions. We examined the relative importance in an offshore gradient of particles greater than $1 \mu \mathrm{m}$ in diameter relative to those less than $1 \mu \mathrm{m}$ in diameter with regard to bacterial numbers and production, and planktonic community respiration. 


\section{MATERIALS AND METHODS}

Three cruises were made on the RV 'Blue Fin' from the Skidaway Institute of Oceanography, Savannah, Georgia, USA, in September and November 1986 and July 1987 . The cruises were designated with the abbreviation BF followed by the date. In 1986, we completed a series of 7 stations beginning in the estuary, passing through the coastal front, and crossing the continental shelf out to a depth of $27 \mathrm{~m}$ (Stn $111 \mathrm{~km}$ inshore, depth $4 \mathrm{~m}$; Stn 2: $1.9 \mathrm{~km}$ inshore, $5 \mathrm{~m}$; Stn 3: $7.4 \mathrm{~km}$ offshore, $6 \mathrm{~m}$; Stn 4: $18.5 \mathrm{~km}, 13 \mathrm{~m} ; \operatorname{Stn} 5$ : $27.8 \mathrm{~km}, 13 \mathrm{~m}$; Stn 6: $44.4 \mathrm{~km}, 16 \mathrm{~m}$; Stn $7: 63 \mathrm{~km}$, $27 \mathrm{~m}$ ). In 1987 we added 2 stations in order to better sample shelf waters (Stn 8: $100 \mathrm{~km}, 38 \mathrm{~m}$; Stn 9: $119 \mathrm{~km}, 55 \mathrm{~m}$ ).

Sampling. At each station surface water temperature was measured using a mercury bucket thermometer. A water sample was taken from a depth of $1 \mathrm{~m}$ using a 51 Niskin bottle (General Oceanics). Salinity was determined using a precision salinometer (AGE Instruments model 2100). We separated samples into 2 treatments: unfiltered water, and water that passed (no vacuum applied) through a $1.0 \mu \mathrm{m}$ Nuclepore filter to obtain a fraction consisting mostly of free-living bacteria. Bacterial numbers, production, and metabolism, as well as planktonic community oxygen consumption, were estimated from samples from the 2 treatments. Additionally, we quantified the organic carbon and nitrogen content of the particulate matter in the unfiltered samples.

Bacterial numbers. Bacterial numbers in the unfiltered and $1.0 \mu \mathrm{m}$-filtered treatments were estimated using acridine orange cell counts (AODC) of samples stained on $0.2 \mu \mathrm{m}$ pore size Nuclepore filters using the method of Hobbie et al. (1977) as modified by Douglas et al. (1987). For BF 7-87 only, bacterial sizes were estimated in both treatments of samples pooled from Stns 1 to 3 and 4 to 9 using the technique of Edwards (1987).

Tritiated thymidine incorporation and amino acid uptake. Triplicate $10 \mathrm{ml}$ subsamples were incubated for $1 \mathrm{~h}$ in the dark with either ${ }^{3} \mathrm{H}$-thymidine (tdr) (New England Nuclear, $80.9 \mathrm{Ci} \mathrm{mmol}^{-1}, 5 \mathrm{nM}$ final concentration) or a tritiated L-amino acid mixture (ICN Radiochemicals $20063,250 \mathrm{mCi} \mathrm{mmol}^{-1}, 0.05 \mu \mathrm{Ci} \mathrm{m} l^{-1}$ final concentration). These concentrations were based on values taken from the literature. Dilution series experiments were not attempted. Incubations began within $30 \mathrm{~min}$ of sample collection. Thymidine incubations were processed as described by Fuhrman \& Azam (1982) using the modifications of Ducklow \& Hill (1985). Samples amended with the amino acid mixture were filtered following incubation onto Nuclepore $0.2 u \mathrm{~m}$ filters. The filters were then rinsed several times with filtered seawater and radioactivity of the filters counted. All thymidine and amino acid uptake values were corrected for passive uptake by subtraction of time-zero blanks obtained from parallel samples.

Community respiration. Community respiration was estimated from change in oxygen concentration over time using a precision respirometer described in detail by Griffith (1988). The respirometer consisted of several $45 \mathrm{ml}$, non-toxic chambers each fitted with a Nester oxygen sensor and a temperature sensor; output from the sensors was linked by an analog-to-digital converter to an Apple Macintosh computer that calculated, displayed, and stored oxygen partial pressure, chamber temperature, and barometric pressure as a function of time. Multiple respirometer chambers were used so that measurements were made on both filtered and unfiltered treatments at the same time. Oxygen concentration was calculated with compensation for the effects of temperature and barometric pressure. Incubations began within 20 min of sample collection and lasted less than $2 \mathrm{~h}$. Incubation temperature was $\pm 1^{\circ} \mathrm{C}$ of in situ temperature.

Particulate organic carbon and nitrogen. Particulate organic carbon (POC) and nitrogen (PON) content of seawater samples was estimated by filtering quadruplicate subsamples of seawater through pre-ashed and pre-weighed Reeve-Angel $984 \mathrm{H}$ glass-fiber filters; filters were then rinsed with $10 \% \mathrm{HCl}$ to dissolve carbonate material, rinsed 3 times with deionized water desiccated, and frozen at $-20^{\circ} \mathrm{C}$. Filters were transported to the laboratory on dry ice where they were reweighed and analyzed for carbon and nitrogen content (Perkin-Elmer $240 \mathrm{C}$ elemental analyzer). The C:N ratio was calculated as POC/PON (by atoms).

\section{RESULTS}

\section{Hydrographic data}

Two of the cruises, BF 9-86 and 7-87, were in summer weather conditions of light variable winds. This season is characterized by strong vertical thermal stratification of shelf waters produced by surface heating. Hot, less saline water extends eastward, over-riding cooler, more saline water that is mixed with intrusions of upwelled Gulf Stream water on a time scale of weeks to months. Intrusions may penetrate to mid-shelf off Georgia. Fresh water is held against the coast by the coastal front (Atkinson et al. 1983). We were not equipped to collect extensive hydrographic data during these cruises, but we can confirm that surface waters of the shelf were warm $\left(28\right.$ to $\left.30^{\circ} \mathrm{C}\right)$ and saline $(35$ to $36 \%$ ), with little horizontal thermal stratification. This is typical of summer conditions (Atkinson et al. 1983, Atkinson 1985). 

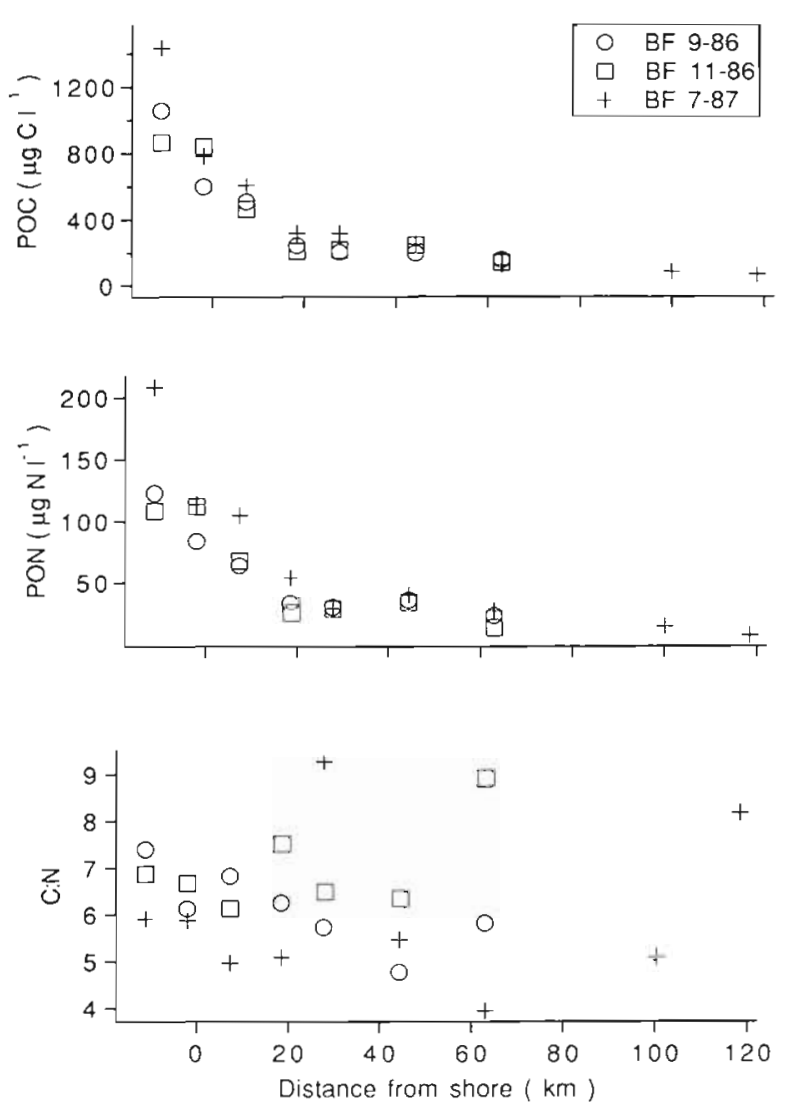

Fig. 1. Particulate carbon (POC), nitrogen (PON), and C:N ratio in surface waters versus distance from shore during 3 cruises (BF 9-86, 11-86 and 7-87)

Surface temperature and salinity data indicated a strong density front near Stns 3 and 4 in November 1986 and July 1987, and a weak density front in September 1986. Fresh water appeared to be held against the coast as predicted by Blanton (1981). Cross-shelf changes in temperature and salinity were typical for the area. We conclude that the transition from coastal to shelf waters was in the vicinity of Stns 3 and 4 .

\section{Offshore gradients in POC, PON, and biological variables}

During all cruises there was a marked decrease in particulate matter from Stns 1 to 4 . This was followed by a relatively slow decline through the stations further offshore (Fig. 1). In all cases, POC and PON were highest in estuarine and nearshore waters (Stns 1 to 3). exhibiting a 2-fold drop between Stns 1 and 2, and 3 and 4 (Fig. 1). The C:N ratio averaged 7.5. There was an apparent decline in the $\mathrm{C}: \mathrm{N}$ ratio with distance offshore (Fig. 1) but this was statistically significant only during BF 9-86 $\left(\mathrm{r}_{\mathrm{s}}=-0.786\right.$; $\left.\mathrm{p}<0.05\right)$. Spearman's rank correlation coefficient $\left(r_{s}\right)$ was used in this and all subsequent correlations because it is a nonparametric test that does not assume a linear relationship between variables.

Bacterial numbers and production also showed significant negative offshore trends (Fig. 2 and Table 1). Bacterial numbers in both size fractions were generally highest at estuarine stations, i.e., 1 and 2, with most of the decrease between Stns 1 and 3, and numbers being fairly uniform over the shelf (Fig. 2). Bac-

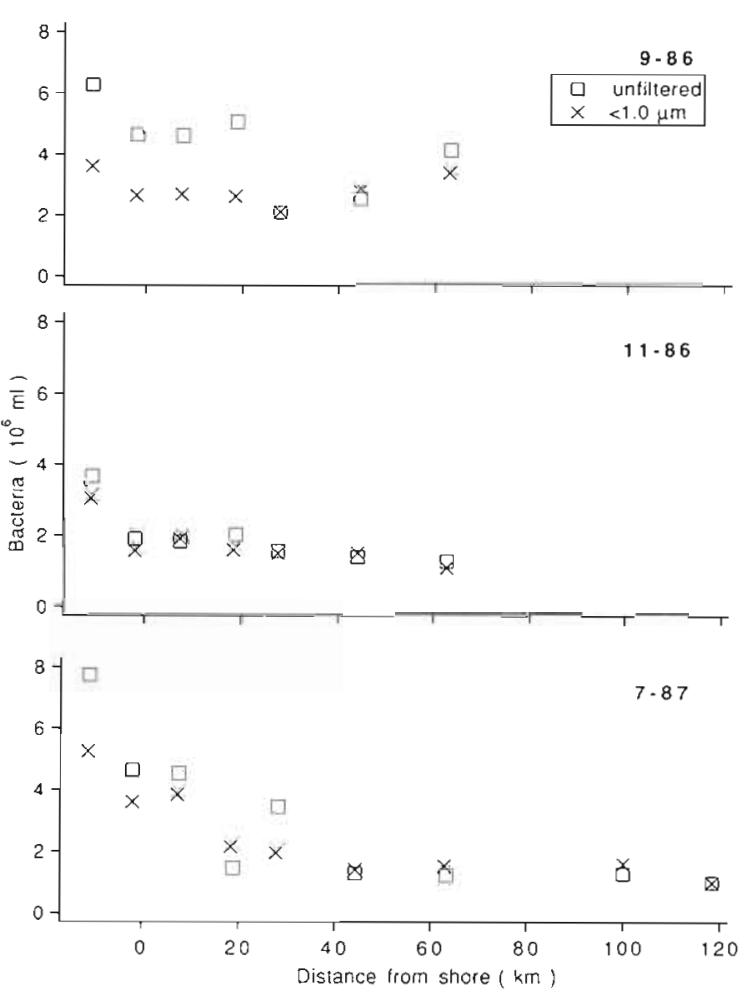

Fig. 2. Bacterial cell counts infiltered and unfiltered treatments versus distance from shore during 3 cruises

Table 1. Correlation coefficients (Spearman's $r_{s}$ ) as a function of distance from shore for respiration, cell counts, thymidine incorporation (Tdr), and amino acid uptake (AA), for both treatments (unfiltered and filtered). Statistics include all stations (1 to 9) during each of 3 cruises (BF 9-86, 11-86, and 7-87)

- $r_{\mathrm{s}}$ values significantly less than zero $(p<0.05)$

\begin{tabular}{|lrrr|}
\hline $\begin{array}{c}\text { Treatment } \\
\text { Variable }\end{array}$ & BF 9-86 & $\begin{array}{c}\text { Cruise } \\
\text { BF 11-86 }\end{array}$ & BF 7-87 \\
\hline Unfiltered & & & \\
Respiration & 0.143 & -0.342 & $0.067^{\circ}$ \\
Cells & $-0.752^{\circ}$ & $-0.893^{\circ}$ & $-0.967^{\circ}$ \\
Tdr & $-0.964^{\circ}$ & $-0.964^{\circ}$ & $-0.967^{\circ}$ \\
AA & $-0.714^{\circ}$ & $-0.107^{\circ}$ & $-0.800^{\circ}$ \\
Filtered & & & \\
Respiration & 0.643 & -0.036 & $0.817^{\circ}$ \\
Cells & -0.071 & $-0.857^{\circ}$ & $-0.917^{\circ}$ \\
Tdr & $-0.821^{\circ}$ & $-0.893^{\circ}$ & $-0.917^{\circ}$ \\
AA & -0.464 & $-0.607^{\circ}$ & $-0.933^{\circ}$ \\
\hline
\end{tabular}




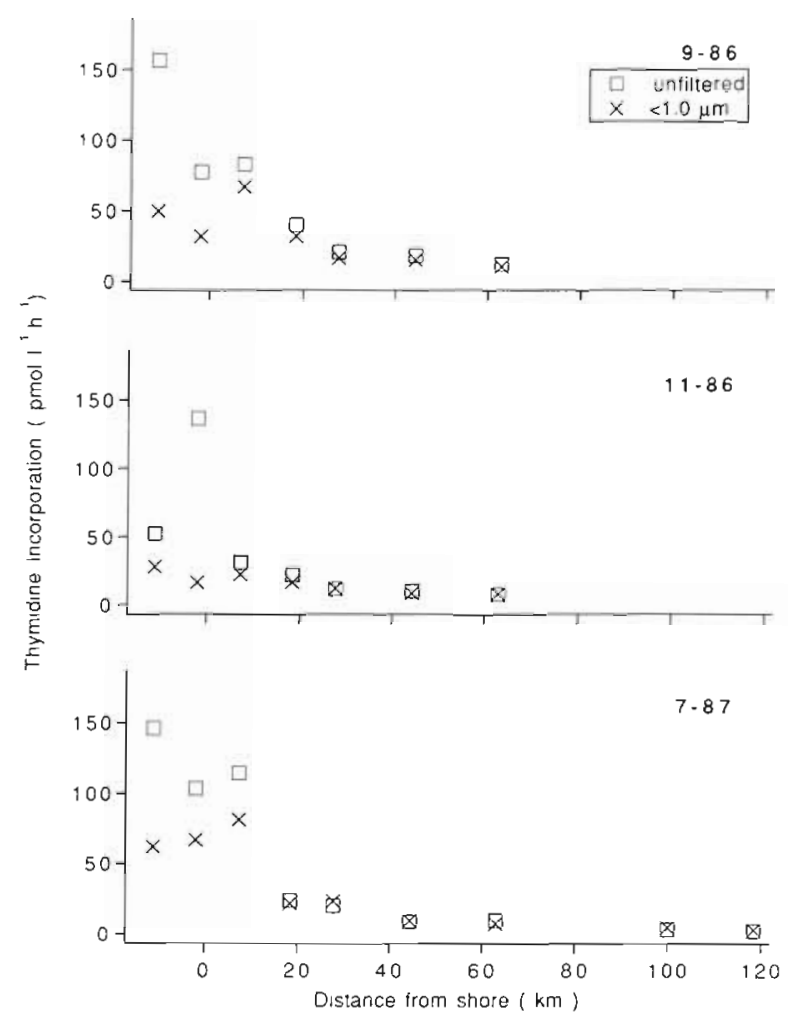

Fig. 3. Rate of thymidine incorporation in filtered and unfiltered treatments versus distance from shore during 3 cruises

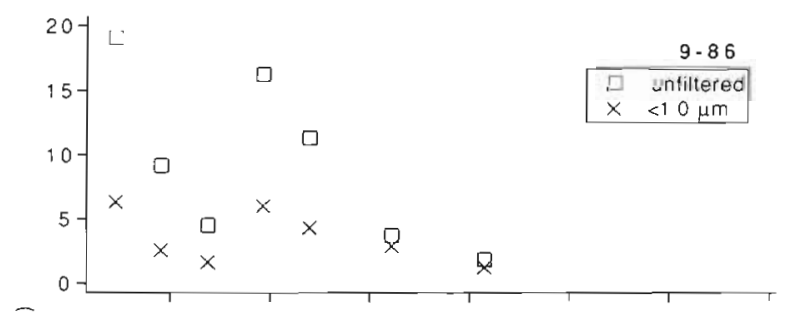

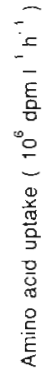
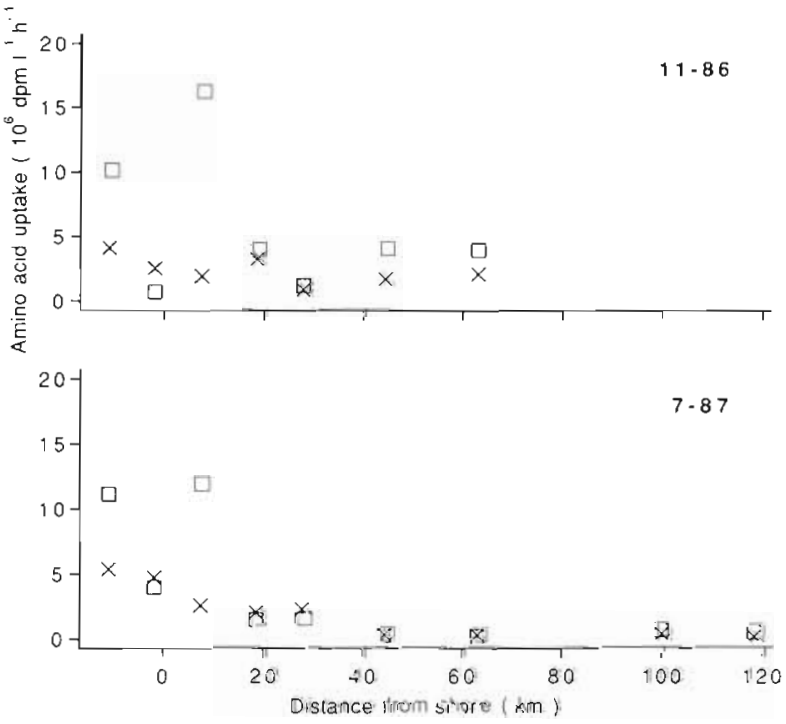

Fig. 4. Rate of amino acid uptake in filtered and unfiltered treatments versus distance from shore during 3 cruises

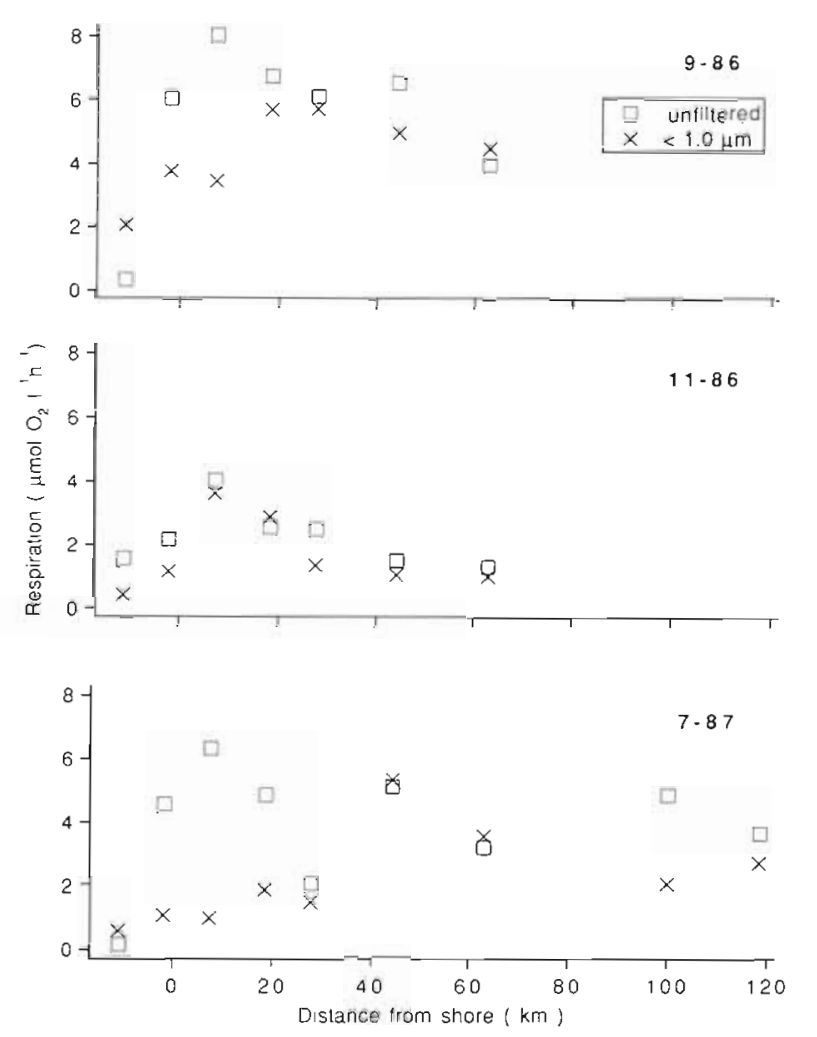

Fig. 5. Community respiration in filtered and unfiltered treatments versus distance from shore during 3 cruises

Table 2. Correlation coefficients (Spearman's $r_{s}$ ) for respiration with distance from shore using the ocean stations ( 3 to 9) only.

- Coefficients significantly less than zero $(p<0.05)$

\begin{tabular}{|llr|}
\hline Cruise & Treatment & $\mathrm{r}_{\mathrm{s}}$ \\
\cline { 2 - 3 } BF 9-86 & Unfiltered & $-0.900^{\circ}$ \\
& Filtered & $0.100^{\circ}$ \\
BF 11-86 & Unfiltered & $-0.900^{\circ}$ \\
& Filtered & $-0.900^{\circ}$ \\
BF 7-87 & Unfiltered & $-0.929^{\circ}$ \\
& Filtered & $-0.857^{\circ}$ \\
\hline
\end{tabular}

terial production declined with distance from shore, ranging from $150 \mathrm{pmol} t \mathrm{dr} \mathrm{l}^{-1} \mathrm{~h}^{-1}$ to 3 pmol tdr $\mathrm{l}^{-1} \mathrm{~h}^{-1}$ (Fig. 3). This decline was consistently significant in both size fractions (Table 1). Within-sample variability in amino acid uptake was more variable than was thymidine incorporation, although rates of amino acid uptake did tend to be lower further from shore (Fig. 4 and Table 1).

Community respiration had a pattern unlike the other biological variables measured. In the unfiltered treatment, respiration was relatively low at estuarine stations ( 1 and 2), peaked at the first nearshore station (3) and decreased significantly across the shelf (Fig. 5 and Table 2). In the filtered treatment, respira- 
tion was relatively low at estuarine stations (Fig. 5). The highest respiration in the filtered treatment was found somewhere between Stns 3,4 and 6. Respiration in the filtered treatment decreased significantly across the shelf during BF 11-86 and 7-87 (Fig. 5 and Table 2).

\section{Bacterial size and volume}

The intent of the filtration treatment was to separate free-living bacteria from the total planktonic community, including particle-associated bacteria. If some freeliving bacteria were greater than $1.0 \mu \mathrm{m}$ in diameter, however, they would not appear with the free-living bacteria in our treatments. In order to estimate how many bacteria might be retained on a $1 \mu \mathrm{m}$ filter, and to estimatc the contribution to biovolume by retained bacteria, we measured bacterial diameter for cocci, and length and diameter for rods, in pooled samples from Stns 1 to 3 and 4 to 9 in both the unfiltered and filtered treatments. In the pooled estuarine and nearshore stations ( 1 to 3 ), $93 \%$ of the bacteria in unfiltered water were small enough to pass a $1.0 \mu \mathrm{m}$ filter. The $7 \%$ too

Table 3. Values of biological variables in filtered treatment, expressed as a percentage of unfiltered treatment for each variable (B: bacteria; Idr: thymidine, AA: amino acids; Resp.: respiration)

\begin{tabular}{|c|c|c|c|c|}
\hline $\begin{array}{l}\text { Cruise and } \\
\text { station }\end{array}$ & B & $T d r$ & AA & Resp. \\
\hline \multicolumn{5}{|l|}{ BF 9-86 } \\
\hline 1 & 57 & 32 & 33 & 680 \\
\hline 2 & 58 & 41 & 28 & 62 \\
\hline 3 & 60 & 81 & 36 & 43 \\
\hline 4 & 53 & 80 & 37 & 85 \\
\hline 5 & 101 & 80 & 38 & 94 \\
\hline 6 & 114 & 83 & 78 & 77 \\
\hline 7 & 85 & 86 & 68 & 114 \\
\hline \multicolumn{5}{|l|}{ BF 11-86 } \\
\hline 1 & 85 & 54 & 41 & 29 \\
\hline 2 & 82 & 12 & 345 & 54 \\
\hline 3 & 104 & 72 & 12 & 91 \\
\hline 4 & 83 & 75 & 83 & 115 \\
\hline 5 & 96 & 102 & 72 & 55 \\
\hline 6 & 108 & 86 & 44 & 70 \\
\hline 7 & 86 & 106 & 53 & 78 \\
\hline \multicolumn{5}{|l|}{ BF $7-87$} \\
\hline 1 & 68 & 42 & 48 & 590 \\
\hline 2 & 78 & 64 & 118 & 24 \\
\hline 3 & 87 & 71 & 22 & 16 \\
\hline 4 & 44 & 90 & 135 & 39 \\
\hline 5 & 59 & 114 & 151 & 74 \\
\hline 6 & 109 & 104 & 114 & 104 \\
\hline 7 & 139 & 76 & 131 & 111 \\
\hline 8 & 124 & 134 & 58 & 43 \\
\hline 9 & 100 & 117 & 35 & 76 \\
\hline
\end{tabular}

big to pass had $57 \%$ of the total bacterial biovolume in the sample. The largest bacterium measured, a coccoid form $2.11 \pm 0.08$ (95\% confidence interval, CI) $\mu \mathrm{m}$ in diameter, was from these stations. At Stns 4 to 9, more than $99 \%$ of the bacteria were small enough to pass the $1.0 \mu \mathrm{m}$ filter. In this case the retained bacteria contributed $11 \%$ to the total biovolume

If filtration had separated bacteria by size only, and not as a function of attachment, we would have expected to find about $93 \%$ of the bacteria from estuarine water, and $99 \%$ of the bacteria from nearshore and shelf waters in the filtered treatment. At all estuarine stations (1 and 2) and nearshore stations (3 and 4) an average of $71 \%$ and $72 \%$, respectively, of bacteria were counted in the filtered treatment as compared to the unfiltered treatment (Tables 3 and 4), implying that a considerable number of bacteria that were small enough to pass the filter, if they had been free-living, were retained by the filter. Of course, some of the bacteria too large to pass may have been attached to particles as well. We conclude that filtration successfully removed many bacteria attached to particles. Similar conclusions have been reached by other investigators in these waters (Hanson \& Wiebe 1977 , Hodson et al. 1981).

One potential pitfall of using fractionated samples is the possibility of small cells, including eukaryotic algae, passing through the filter and multiplying in the filtrate to significant cell densities (cf. Li \& Dickie 1984, Cynar et al. 1985). Algae could only contribute to respiration rates, not uptake of thymidine or amino acids, and epifluorescent microscopic examination revealed few autofluorescent organism in the samples relative to the number of heterotrophic bacteria. Moreover, our incubations were sufficiently short $(<2 \mathrm{~h})$ that cell proliferation could not have been a problem. Short incubations also reduced changes in bacterial activity due to effects of confinement (Ferguson et al. 1984)

Table 4. Activity or bacterial numbers in the $<1.0 \mu \mathrm{m}$ fraction expressed as a percentage of the same in unfiltered water. One-way factorial ANOVA's were performed on bacterial (B) numbers, thymidine incorporation ( $\mathrm{Tdr}$ ), amino acid uptake (AA), and community respiration (Resp.) data, using water type as the source of variation. For each of these variables. water types marked with an asterisk are statistically different (Fisher PLSD, $\mathrm{p}<0.05$ ). We excluded respiration data from Stn 1 during $9-86$ and $7-87$ because of the much greater amount of respiration found in the filtered versus unfiltered water (Table 3)

\begin{tabular}{|lrlrl|}
\hline Water type & B & Tdr & AA & Resp. \\
\hline Estuarine & 71 & $41^{\circ}$ & 102 & $42^{\circ}$ \\
Nearshore & 72 & $78^{\circ}$ & 54 & 65 \\
Shelf & $102^{\circ}$ & $99^{\circ}$ & 77 & 81 \\
\hline
\end{tabular}




\section{Activity in filtered and unfiltered treatments}

We assessed the relative number or activity of bacteria (or planktonic community in the case of respiration) in the filtered treatment relative to the unfiltered treatment by expressing the amount of each variable estimated in the filtered treatment as a percentage of the paired unfiltered treatment. There were differences in rate measurements (thymidine incorporation, amino acid uptake, and community respiration) between unfiltered and filtered treatments (Table 3). The estuarine and nearshore stations generally had a lower percentage of thymidine incorporation by free-living bacteria during all cruises. For amino acid incorporation the percent activity associated with the size fraction $<1 \mu \mathrm{m}$ varied greatly, without obvious relationship to the different waters sampled. The smallest percentages of community respiration in filtered water were at Stns 2 to 4 . Community respiration in the filtered water was greater than in the unfiltered water at estuarine Stn 1 on 2 of the 3 cruises.

\section{DISCUSSION}

\section{Relative importance of free-living bacteria}

In order to make general statements about the activity of free-living bacteria along the series of stations from estuary to shelf-break, we divided the percentactivity data from Table 3 by water type and cruise for analysis of variance (ANOVA). This approach gave us multiple samples for each cruise and for each water type. Three water types were assigned: Stns 1 and 2 were classified as estuarine; Stns 3 and 4 , which were in the vicinity of the coastal front, were classified as nearshore; and Stns 5 to 9 as shelf. Two-way factorial ANOVA by water type and cruise demonstrated no effect between cruises, and no interaction between cruise and water type (Scheffe F-test, p > 0.05), so we pooled the cruise data for a 1-way factorial ANOVA by water type alone.

This analysis revealed unambiguous differences in the relative importance of free-living bacteria between the water types (Table 4). Free-living bacteria represented about $70 \%$ of total bacterial numbers in estuarine and nearshore waters, as opposed to near $100 \%$ in shelf waters. Free-living bacteria were responsible for an increasing percentage of total thymidine incorporation in estuarine $(41 \%)$, nearshore $(78 \%)$, and shelf $(99 \%)$ waters. Moreover, the respiration of organisms in the filtered fraction accounted for an increasing percentage of total community respiration, from $42 \%$ in estuarine water, to $65 \%$ in nearshore and $81 \%$ in shelf water. Because epifluorescent exami- nation revealed that heterotrophic bacteria comprised almost all the microorganisms in the $<1.0 \mu$ m fraction and there were very few larger or particle-associated bacteria in these samples, the small, free-living bacteria were responsible for ca $81 \%$ of community respiration in shelf water. Larger planktonic heterotrophs were apparently responsible for the remaining $19 \%$ of community respiration in shelf water. Recent evidence indicates that much of the organic matter available in estuarine and nearshore waters is mineralized by bacteria (Hopkinson et al. 1989). Our data support this contention and indicate that heterotrophic bacteria may mineralize much of the organic matter in outer shelf waters as well.

Although particle-associated bacteria represented about $30 \%$ of bacterial numbers in the estuarine water, they were responsible for a higher percentage of metabolic activity as indicated by thymidine incorporation. This may reflect the greater biovolume of bacteria in these waters; we estimated that bacteria greater than $1.0 \mu \mathrm{m}$ in diameter comprised $75 \%$ of bacterial biovolume.

We were unable to discern a significant difference in amino acid uptake between water types, in contrast to the other variables. It must be noted, however, that the variability of amino acid uptake was considerably larger than that of the other variables (Figs. 1 to 5). The inability to show differences between water types for amino acid uptake may have been due, to a large part, to the greater variability in estimates from estuarine and nearshore waters as compared to shelf waters (Fig. 4).

\section{Bacterial carbon metabolism}

Gross growth efficiency of bacteria can be calculated by expressing both community respiration in the filtered fraction and thymidine incorporation as weight of carbon per unit time based on several assumptions. To convert community respiration (umol $\mathrm{O}_{2} \mathrm{l}^{-1} \mathrm{~h}^{-1}$ ) to

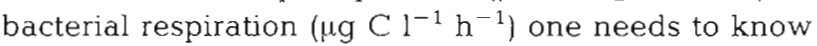
the proportion of community respiration due to bacteria, and the ratio of carbon mineralized to oxygen reduced ( $R Q$ ) by the bacteria. We used a (conservative) estimate that $90 \%$ of respiration in the filtered treatment was bacterial. To our knowledge there are no measurements of the RQ of natural populations of bacteria growing on natural substrates. Estimates of bacterial $R Q$ during growth on more reduced substrates in laboratory culture range from ca 0.6 to 0.9 (Battley 1987). We used a (conservative) estimate of $R Q=0.7$ based on these values. Finally, we converted thymidine

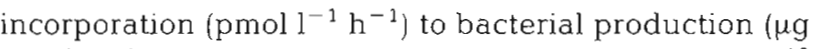
$\mathrm{C}^{-1} \mathrm{~h}^{-1}$ ) assuming the conversion factors $1.18 \times 10^{18}$ cells $\mathrm{mol}^{-1} \mathrm{tdr}$ (Rieman et al. 1987), and $20 \mathrm{fg} \mathrm{C} \mathrm{cell}^{-1}$ 
(Lee \& Fuhrman 1987). Using these assumptions, we calculated gross growth efficiencies of 11,6 , and $2 \%$ in estuarine, nearshore, and shelf waters, respectively. This trend would be even more dramatic if we assumed all respiration to be bacterial, or $R Q=1$, or if we had accounted for the decrease in bacterial size across the transect.

The growth efficiencies indicate inefficient growth of bacteria in estuarine and nearshore waters, similar to what has been found in bacteria growing on detritusprepared marsh grasses (Linley \& Newell 1984, Newell 1984). This is in contrast to the very high growth efficiency ( 75 to $90 \%$ ), based on uptake of ${ }^{14} \mathrm{C}$-labeled glucose, found in estuarine and coastal waters near Sapelo Island, Georgia (Hanson \& Wiebe 1977). We found the growth efficiency in shelf water was even lower, though not as low as the near-zero growth efficiency on natural substrates, reported for bacteria in shelf water of the Grand Banks of Newfoundland (Smith et al. 1986). Despite evidence that $50 \%$ is the lower threshold for growth efficiency of marine bacteria on glucose and amino acids (Goldman et al. 1987), we suggest that it may generally be true that natural populations of marine bacteria, growing on natural substrates, grow inefficiently. Low bacterial growth efficiency is incompatible with significant transfer of organic carbon from microheterotrophs to higher organisms (Williams 1981, Sherr \& Sherr 1988).

\section{Trophic interactions among microbes}

A recent theoretical treatment of carbon- and energy-flow in pelagic food webs proposed biotic-feedback mechanisms in pelagic microbial food webs which originate due to trophic interactions within the web itself (Sherr et al. 1988). These feedback mechanisms purportedly serve to regulate carbon flow between bacteria, ciliates, flagellates, and higher organisms. Part of the experimental evidence used to support the existence of trophic interactions was that oxygen consumption in filtered treatments was greater than that in unfiltered water in many estuarine samples with high $\mathrm{C}: \mathrm{N}$ ratios, but not in samples from coastal waters having relatively lower $\mathrm{C}: \mathrm{N}$ ratios (Hopkinson et al. 1989). Sherr et al. (1988) suggested that the higher respiration was the result of a stimulation in bacterial metabolism induced by lack of nitrogen, which might be less available following filtration because of removal of protozoa that had been consuming bacteria and regenerating nitrogen.

The sampling locations used by Hopkinson et al. (1989) and in this study have comparable stations. Their stations began higher in the estuary than our Stn 1, and extended to approximately the equivalent of our Stn 3 in the nearshore zone. Hopkinson et al. (1989) found the greatest enhancement of respiration in the $<1 \mu \mathrm{m}$ fraction in the upper estuary; enhancement was absent in the nearshore zone. In 2 of the 3 respiration measurements at our estuarine station (1) there was considerably more respiration in the filtered fraction than in the unfiltered sample (Table 3). We found no stimulation by filtration at our estuarine Stn 2 or nearshore Stn 3 . We did not explicitly test the proposed explanation of the stimulation effect, but we did find much the same pattern observed by Hopkinson et al. (1989).

\section{CONCLUSIONS}

Overall, our results show a marked offshore transition from a particle-rich to a particle-poor environment in the waters of the Georgia Bight. Small, free-living bacteria are dominant throughout the different water types. However, the importance of larger as well as particleassociated bacteria increases in estuarine and nearshore waters. The evidence that free-living bacteria grow with low efficiency and are responsible for 80 to $99 \%$ of pelagic community respiration has great significance to carbon budgets of the continental shelf.

Acknowledgements. This work was supported by U.S. Department of Energy grant DE-FG09-86ER60451 to L. R. Pomeroy. We were assisted with cell counts and bacterial size measurements by $M$. Wiebe and L. Leff. Many useful editorial comments were provided by E. Fleischmann, C. Hopkinson, L. Pomeroy, and an anonymous reviewer.

\section{IITERATURE CITED}

Atkinson, L. P. (1985). Hydrography and nutrients of the southeastern U.S. continental shelf. In: Atkinson, L. P., Menzel, D. W., Bush, K. A. (eds.) Oceaonography of the southeastern U.S. continental shelf. American Geophysical Union, Washington D.C., p. 1-9

Atkinson, L. P., Lee, T N., Blanton, J. O., Chandler, W. S. (1983). Climatology of the southeastern United States continental shelf waters. J. geophys. Res. 88: 4705-4718

Battley, E. H. (1987). Energetics of microbial growth. Wiley, New York

Blanton, J. O. (1981). Ocean currents along a nearshore frontal zone on the continental shelf of the southeastern United States. J. phys. Oceanogr. 11: 1627-1637

Cynar, F. J., Estep, K. W. Sieburth, J. McN. (1985). The detection and characterization of bacteria-sized protists in protist-free' filtrates and their potential impact on experimental marine ecology. Microb. Ecol. 11. 281-288

Douglas, D. J., Novitsky, J. A., Fournier, R. O. (1987). Microautoradiography-based enumeration of bacteria with estimates of thymidine-specific growth and production rates. Mar. Ecol. Prog. Ser. 36: 91-99

Ducklow, H. W., Hill, S. M. (1985). The growth of heterotrophic bacteria in the surface waters of warm core rings. Limnol. Oceanogr. 30: $239-259$ 
Ducklow, H. W., Kirchman, D. L. (1983). Bacterial dynamics and distribution during a spring diatom bloom in the Hudson River plume, U.S.A. J. Plankton Res. 5: 333-354

Edwards. R. T (1987). Seasonal bacterial biomass dynamics in the seston of two Southeastern blackwater rivers. Limnol. Oceanogr. 32: 221-234

Ferguson, R. L., Buckley, E. N., Palumbo, A. V. (1984). Response of marine bacterioplankton to differential filtration and confinement. Appl. envirl Microbiol. 47: 49-55

Fuhrman, J. A., Azam, F. (1982). Thymidine incorporation as a measure of heterotrophic bacterioplankton production in marine surface waters: evaluation and field results. Mar Biol. 66: 109-120

Goldman, J. C., Caron, D. A., Dennett, M. R. (1987). Regulation of gross growth efficiency and ammonium regeneration in bacteria by substrate $\mathrm{C}: \mathrm{N}$ ratio. Limnol. Oceanogr. 32 : $1239-1252$

Griffith, P. C. (1988). A high-precision respirometer for measuring small rates of change in the oxygen concentration of natural waters. Limnol. Oceanogr. 33: 632-638

Hanson, R. B., Wiebe, W. J. (1977). Heterotrophic activity associated with particulate size fractions in a Spartina alterniflora salt-marsh estuary, Sapelo Island, Georgia, USA, and the continental shelf waters. Mar. Biol. 42: 321-330

Hobbie, J. E., Daley, R. J., Jasper, S. (1977). Use of Nuclepore filters for counting bacteria by fluorescence microscopy. Appl. envirl Microbiol. 33: 1225-1228

Hodson, R. E., Maccubbin, A. E., Pomeroy, L. R. (1981). Dissolved adenosine triphosphate utilization by free-living and attached bacterioplankton. Mar. Biol. 64: 43-61

Hopkinson, C. S., Sherr, B. , Wiebe, W. J. (1989). Size fractionated metabolism of coastal microbial plankton. Mar. Ecol. Prog. Ser. 51: 155-166

Lee, S., Fuhrman, J. A. (1987). Relationships between biovolume and biomass of naturally derived marine bacterioplankton. Appl. envirl Microbiol. 53: 1298-1303

Li, W. K. W., Dickie, P. M. (1984). Rapid enhancement of heterotrophic but not photosynthetic activities in arctic microbial plankton at mesobiotic temperatures. Polar. Biol. 3: 217-226

Linley, E. A. S., Newell, R. C. (1984). Estimates of bacterial

This article was presented by Drs E. and B. Sherr, Sapelo Island, Georgia, USA growth yields based on plant detritus. Bull. mar Sci. 35: $409-425$

Newell, R. C. (1984). The biological role of detritus in the marine environment. In: Fasham, M. J. R. (ed.) Flows of energy and materials in marine ecosystems: theory and practice. Plenum, New York, p. 317-343

Pomeroy, L. R. (1974). The ocean's tood web, a changing paradigm. BioSci. 24. 499-504

Pomeroy, L. R., Johannes, R. E. (1966). Total plankton respiration. Deep Sea Res. 13: 971-973

Pomeroy, L. R., Johannes, R. E. (1968). Occurrence and respiration of ultraplankton in the upper 500 meters of the ocean. Deep Sea Res. 15: 381-391

Rieman, B., Bjørnsen, P. K. Newell, S., Fallon, R. (1987). Calculation of cell production of coastal marine bacteria based on measured incorporation of $\left[{ }^{3} \mathrm{H}\right]$ thymidine. Limnol. Oceanogr. 32: 471-476

Sherr, B. F., Sherr, E. B., Hopkinson, C. S. (1988). Trophic interactions within pelagic microbial communities: indications of feedback regulation of carbon flow. Hydrobiologia 159: $19-26$

Sherr, E. B., Sherr, B. F. (1988). Role of microbes in pelagic food webs: a revised concept. Limnol. Oceanogr. 33: $1225-1227$

Smith, R. E. H., Harrison, W. W., Irwin, B., Platt, T (1986). Metabolism and carbon exchange in the microplankton of the Grand Banks (Newfoundland). Mar Ecol. Prog. Ser. 34: 171-183

Wangersky, P. J. (1984). Organic particles and bacteria in the ocean. In: Hobbie, J. E., Williams, P. J. leB. (eds.) Heterotrophic activity in the sea. Plenum, New York, p. 263-288

Wiebe, W. J., Pomeroy, L. R. (1972). Microorganisms and their association with aggregates and detritus in the sea: a microscopic study. Memorie Ist. ital. Idrobiol., 29 Suppl.: 325-353

Williams, P. J. leB. (1981). Incorporation of microheterotrophic processes into the classical paradigm of the planktonic food web. Kieler Meeresforsch. (Sonderh.) 5: 1-28

Williams, P. J. leB. (1984). A review of measurements of respiration rates of marine plankton populations. In: Hobbie, J. E., Williams, P. J. leB. (eds.) Heterotrophic activity in the sea. Plenum, New York, p. 357-390

Manuscript first received: February 8, 1989

Revised version accepted: October 4, 1989 